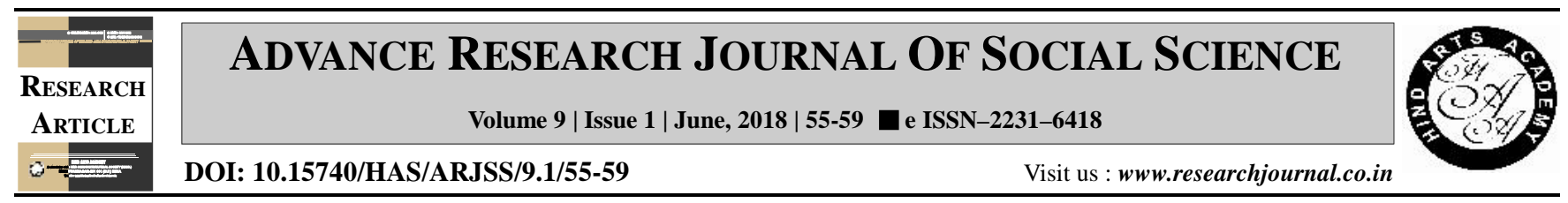

\title{
A study on perception towards distance education - Factor analysis
}

M. Malarkodi*, S. Praveena and T. Samsai

Department of Agricultural Rural Management, Tamil Nadu Agricultural University, Coimbatore (T.N.) India

(Email: malardeepshik@gmail.com, sspriyamba@gmail.com)

\section{ARTICLE INFO :}

$\begin{array}{lll}\text { Received } & : & 20.01 .2018 \\ \text { Revised } & : & 27.04 .2018 \\ \text { Accepted } & : & 14.05 .2018\end{array}$

\section{KEY WORDS :}

Distance education, Factor analysis, Perception

\section{HOW TO CITE THIS ARTICLE :}

Malarkodi, M., Praveena, S. and Samsai, T. (2018). A study on perception towards distance education - Factor analysis. $A d v$. Res. J. Soc. Sci., 9 (1) : 55-59, DOI: 10.15740/HAS/ARJSS/9.1/55-59.

Copyright@2018 : Hind Agri -

Horticultural Society

*Author for correspondence

\begin{abstract}
In India online education was in its primitive stage. Though, maximum educational institutes had adopted the process of online admission and online result announcement, but the method of teaching through online was relatively slow in India. It was important for the universities to understand the perception of students towards online learning. Accordingly this study was conducted to understand the perception of the students towards the distance education so that universities could develop strategies to initiate online courses. In order to understand the perception towards distance education, factor analysis was attempted. The total sample size was 180 students consisting of 90 agricultural students and 90 non agricultural students. A well structured questionnaire was prepared to collect the required information. From the results it was found that the students perceived the distance education positively because it was linked to online course attributes, convenient learning process, flexibility in communication and personal attributes.
\end{abstract}

